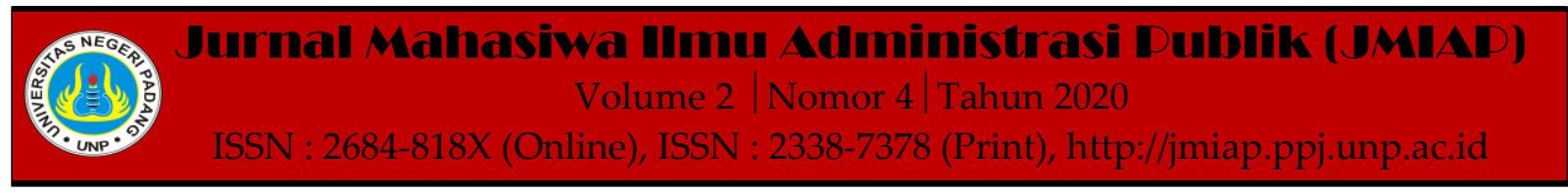

\title{
PELAKSANAAN FUNGSI PENGAWASAN OMBUDSMAN RI PERWAKILAN SUMATERA BARAT TERHADAP PELAYANAN PUBLIK
}

\author{
M. Rafi Ariansyah ${ }^{1(a)}$, Rahmadani Yusran ${ }^{2(b)}$ \\ ${ }^{1}$ Jurusan Ilmu Administrasi Negara, Universitas Negeri Padang \\ ${ }^{2}$ Jurusan Ilmu Administrasi Negara, Universitas Negeri Padang \\ a)mrafiariansyah@gmail.com, ${ }^{b}$ yusranrdy@fis.unp.ac.id
}

\begin{abstract}
This study aims to determine the implementation of the oversight function of the Ombudsman RI Representatives of West Sumatra on public services and also to determine the inhibiting factors for the implementation of the supervision of the Ombudsman RI Representatives of West Sumatra to public services in West Sumatra Province. This research uses a qualitative approach with descriptive methods. The results of this study are: 1. Implementation of the oversight function of the Indonesian Ombudsman Representative of West Sumatra on public services in West Sumatra Province which is carried out in 2 (two) fields, namely the field of report inspection and the field of prevention. In the field of report examination, the Indonesian Ombudsman Representative of West Sumatra receives reports, checks reports, follows up reports, carries out investigations, provides recommendations, and conducts monitoring. Meanwhile, in the field of prevention, the Indonesian Ombudsman, the West Sumatra Representative, has made efforts to prevent maladministration by empowering the community which aims to increase public awareness so that they can work together with the Indonesian Ombudsman Representative of West Sumatra in overseeing the implementation of public services in West Sumatra Province. 2. Inhibiting factors in the implementation of the supervision of the Indonesian Ombudsman Representative of West Sumatra on public services in West Sumatra Province is that the Ombudsman finds obstacles and obstacles in the form of a lack of human resources, the absence of a representative Ombudsman in the Regency / City, and a lack of budget.
\end{abstract}

Keywords : Supervision, Ombudsman, Public Service

Corresponding author. Email.mrafiariansyah@gmail.com

How to cite this article. Ariansyah, M. Rafi \& Yusran, R. (2020). Pelaksanaan Fungsi Pengawasan Ombudsman RI Perwakilan Sumatera Barat terhadap Pelayanan Publik. Jurnal Mahasiwa Ilmu Administrasi Publik (JMIAP) Jurusan Ilmu Administrasi Negara Fakultas Ilmu Sosial Universitas Negeri Padang, Volume 2 (4), Hal. 1-9.

http://jmiap.ppj.unp.ac.id

ISSN : 2684-818X (Online), ISSN : 2338-7378 (Print)

Copyright $\odot 2020$. Published by Labor Jurusan Ilmu Administrasi Negara FIS UNP, Padang

1 | Jurnal Mahasiwa Ilmu Administrasi Publik | Volume 2 | Nomor 4 | Tahun 2020 | (Hal. 1-9) 


\section{PENDAHULUAN}

Sejalan dengan semangat reformasi yang bertujuan menata kembali perikehidupan berbangsa dan bernegara, pemerintah telah melakukan perubahanperubahan mendasar dalam sistem ketatanegraan dan sistem pemerintahan Republik Indonesia. Perubahan dilakukan antara lain dengan membentuk lembaga-lembaga negara dan lembaga-lembaga pemerintahan baru, salah satu diantaranya adalah Komisi Ombudsman atau yang lazim disebut Ombudsman Nasional. Seiring perjalanan waktu, melalui Keppres Nomor 44 Tahun 2000 Komisi Ombudsman Nasional hadir sebagai manifestasi konkret bahwa rakyat juga berhak mendapatkan perlakuan secara prioritas dalam hal pelayanan publik. Tugas pokoknya adalah melakukan pengawasan terhadap proses pelayanan umum oleh penyelenggara negara. Salah satu tujuannya adalah mendorong penyelenggaraan negara dan pemerintahan yang efektif, efisien, jujur, terbuka, dan bersih, serta bebas dari korupsi, kolusi, dan nepotisme sesuai dengan ketentuan Pasal 4 huruf b UndangUndang Nomor 37 Tahun 2008 tentang Ombudsman Republik Indonesia. Untuk mempertegas eksistensinya maka dikeluarkanlah Undang-Undang Nomor 37 Tahun 2008 tentang Ombudsman Republik Indonesia. Dengan demikian, maka keberadaan Ombudsman Nasional tersebut dalam sistem pemerintahan negara adalah sebagai lembaga yang membantu menciptakan dan meningkatkan upaya untuk pemberantasan dan pencegahan praktek-praktek maladministrasi, diskriminasi, kolusi, korupsi, serta nepotisme sesuai dengan ketentuan Pasal 4 huruf d UndangUndang Nomor 37 Tahun 2008 tentang Ombudsman Republik Indonesia.

Untuk mencapai harapan tersebut, pemerintahan Provinsi Sumatera Barat mengesahkan peraturan tentang pelayanan publik, yaitu Peraturan Gubernur Sumatera
Barat Nomor 62 Tahun 2016 tentang Tata Cara Pengelolaan Pengaduan Pelayanan Publik di Lingkungan Provinsi Sumatera Barat. Namun dalam aturan tersebut, Ombudsman sebagai lembaga pengawas sektor pelayanan publik tidak disebutkan, hingga akhirnya pada tahun 2016, pemerintah Kota Padang mengeluarkan Peraturan Walikota Padang Nomor 15 Tahun 2018 tentang Pendelegasian Kewenangan Penyelenggaraan Pelayanan Terpadu Kepada Dinas Penanaman Modal dan Pelayanan Terpadu Satu Pintu yang dalam peraturan tersebut menguatkan fungsi dan kedudukan Ombudsman sebagai lembaga pengawas pelayanan publik. Meskipun sudah dibarengi dengan aturan yang cukup memadai, ternyata masih banyak laporan-laporan yang masuk terkait kinerja para penyelenggara pelayanan publik. Hal tersebut dapat diamati dari tingkat keluhan dari tahun ke tahun, Pada tahun 2017 terjadi peningkatan kasus yang masuk ke Ombudsman RI Sumatera Barat sebesar 270 laporan.Peningkatan ini diperkirakan akibat tingginya kesadaran serta sarana dan prasarana laporan yang cukup memadai. Dari 270 aduan masyarakat yang di terima Ombudsman RI Perwakilan Sumbar 151 Laporan diantaranya atau sekitar 53 persen pengaduan terkait pelayanan publik oleh Pemerintah Daerah terutama pemerintah kabupaten dan kota, didominasi laporan layanan di SKPD, Kantor Kecamatan dan Kelurahan (Data-Ombudsman-RISumatera Barat).

Laporan yang diadukan masyarakat ke Ombudsman Sumatera Barat diantaranya permasalahan perhubungan, pendidikan, perumahan, kesehatan, perizinan, pertanahan retribusi, pemakaman, fasilitas umum, serta kepegawaian dilingkungan kantor tersebut. Di Kabupaten Pesisir selatan sebanyak 13 laporan, Payakumbuh sebanyak 7 laporan, Kabupaten Lima Puluh Kota dan Agam sebanyak 6 laporan, dan 
Kabupaten Pasaman Barat 5 laporan. Sedangkan substansi laporan 16 persen atau 44 laporan terkait layanan pendidikan seperti pungutan dan sumbangan pendidikan, ujian nasional dan sertifikasi guru serta penerimaan sisiwa baru, 11 persen terkait seleksi Calon Pegawai Negeri Sipil (CPNS) serta 10 persen atau 27 laporan masalah pertanahan. Sementara itu dari 270 pengaduan yang masuk, semuanya sudah ditindaklanjuti. Namun baru 153 laporan atau sekitar 56 persen lebih yang baru diselesaikan.

Berdasarkan uraian diatas, maka penulis merasa perlu untuk lebih mendalami Pelaksanaan fungsi pengawasan Ombudsman RI Perwakilan Sumatera Barat terhadap Pelayanan Publik (Mukti Fajar 2010:180)

\section{TINJAUAN PUSTAKA}

\section{Konsep Pengawasan}

Menurut Admosudirjo (dalam Andri, 2015:63-64) mengatakan, bahwa pengawasan merupakan keseluruhan kegiatan yang membandingkan atau mengukur apa yang sedang atau sudah dilaksanakan dengan kriteria, norma-norma, standar, atau rencana-rencana yang telah ditetapkan sebelumnya. Handoko (2014:359) mengatakan bahwa, pengawasan manajemen adalah suatu usaha sistematik untuk menetapkan standar pelaksanaan dengan tujuan perencanaan, merancang sisem informasi umpan balik, membandingkan kegiatan nyata dengan standar, menentukan dan mengukur penyimpangan-penyimpangan, serta mengambil tindakan koreksi yang diperlukan untuk menjamin bahwa semua sumber daya perusahaan dipergunakan dengan cara paling efektif dan efisien dalam pencapaian tujuan-tujuan perusahaan.

Dapat dismpulkan bahwa pengawasan dilakukan untuk menjamin semua kegiatan sesuai dengan kebijaksanaan, strategi, keputusan, rencana, dan program kerja yang telah dianalisis, dirumuskan dan ditetapkan sebelumnya serta diselenggarakan dalam wadah yang telah tersusun untuk tujuan tertentu.Penyelenggaraan suatu usaha memerlukan adanya pengawasan.Jika dalam organisasi terjadi penyimpangan, maka pengawasan dapat dilakukan tindakan perbaikan.

\section{Fungsi dan Tujuan Pengawasan}

Menurut Arifin Abdul Rachman (2001:23) pengawasan mempunyai tujuan sebagai berikut:

a. Menjamin ketetapan pelaksanaan sesuai dengan rencana, kebijakan dan perintah;

b. Menerbitkankoordinasi;

c. Kegiatan-kegiatan yang mencegah pemborosan dan penyelewengan;

d. Menjamin terwujudnya kepuasan masyarakat atas barang atau jasa yang dihasilkan;

e. Membina kepercayaan masayrakat terhadap kepemimpinan organisasi Dengan demikian mengenai tujuan pengawasan yang sangat erat kaitannya dengan rencana dari suatu organisasi.

\section{Bentuk-bentuk Pengawasan}

Menurut Situmorang (2008:28) di Indonesia terdapat berbagai macam bentuk pengawasan antara lain, sebagai berikut:

1) Pengawasan langsung dan tidak langsung. Pengawasan langsung adalah pengawasan yang dilakukan secara pribadi oleh pemimpin atau pengawas dengan mengamati, meneliti, memeriksa, mengecek sendiri secara on the spot di tempat pekerjaan, dan menerima laporan-laporan secara langsung dari pelaksana. Hal ini dilakukan dengan inspeksi. Sedangkan pengawasan tidak langsung diadakan dengan mempelajari laporan- laporan yang diterima dari pelaksana baik lisan maupun tulisan, mempelajari pendapat 
masyarakat dan sebagainya tanpa on the spot.

2) Pengawasan Preventif dan Represif. Pengawasan preventif adalah pengawasan yang bersifat mencegah. Mencegah artinya menjaga jangan sampai suatu kegiatan itu jangan sampai terjerumus pada kesalahan. Pengawasan ini bersifat mencegah agar pemerintah daerah tidak mengambil kebijakan yang bertentangan dengan peraturan perundang-undangan yang berlaku. Sedangkan pengawasan represif adalah pengawasan yang berupa penangguhan atau pembatalan terhadap kebijakan yang telahditetapkan daerah baik berupa Peraturan Daerah, Peraturan Kepala Daerah, Keputusan DPRD maupun Keputusan Pimpinan DPRD dalam rangka penyelenggaraan pemerintahan daerah. Pengawasan represif berupa penangguhan atau pembatalan terhadap kebijakan daerah yang dinilai bertentangan dengan kepentingan umum, peraturan perundang-undangan yang lebih tinggi atau peraturan perundang-undangan yang lainnya.

3) Pengawasan Internal dan Eksternal. Pengawasan internal adalah pengawasan yang dilakukan oleh aparat dalam organisasi itu sendiri. Pengawasan ini lebih dikenal dengan pengawasan fungsional. Pengawasan fungsional adalah pengawasan terhadap pemerintah daerah, yang dilakukan secara fungsional oleh lembaga yang dibentuk untuk melaksanakan pengawasan fungsional, yang kedudukannya merupakan bagian dari lembaga yang diawasi seperti Inspektorat Jenderal, Inspektorat Provinsi, Inspektorat Kabupaten/Kota. Sementara pengawasan eksternal adalah pengawasan yang dilakukan oleh aparat dari luar organisasi itu sendiri seperti Badan Pemeriksa Keuangan (BPK),
Ombudsman Republik Indonesia, dan Komisi Pemberantasan Korupsi (KPK).

\section{METODE PENELITIAN}

Penelitian ini menggunakan pendekatan kualitatif dengan metode deskriptif. Penelitian kualitatif adalah prosedur penelitian yang menghasilkan data deskriptif berupa kata-kata tertulis atau lisan dari orang-orang dan perilaku yang dapat diamati. Penelitian kualitatif dengan metode deskriptif adalah suatu jenis penelitian yang bertujuan untuk membuat deskripsi, atau gambaran secara sistematis, faktual dan akurat mengenai fakta-fakta, sifat-sifat serta hubungan antara fenomena yang diselidiki. Penelitian dilakukan di Kantor Ombudsman RI Perwakilan Sumatera Barat.

Informan penelitian diperoleh dengan menggunakan teknik purposive sampling yaitu menentukan informan dengan pertimbangan tertentu yanng dipandang dapat memahami secara mendalam tentang informasi yang akan peneliti dapatkan dan juga memberikan waktu dan data yang diperlukan dalam penelitian memberikan data secara maksimal (Moleong, 2005:132). Informan penelitian meliputi Kepala Ombudsman RI Perwakilan Sumatera Barat, Kepala Keasistenan Bidang Pencegahan Ombudsman RI Perwakilan Sumatera Barat, Kepala Keasistenan Bidang Verifikasi dan Pemeriksaan Laporan Ombudsman RI Perwakilan Sumatera Barat, dan Asisten Bidang Pencegahan Ombudsman RI Perwakilan Sumatera Barat.

Data yang digunakan berupa data primer yang bersumber dari wawancara dan observasi secara langsung dengan informan serta meliputi data sekunder yang didapatkan berupa dari hasil studi dokumentasi dan. Tingkat validitas terhadap penelitian ini berupa kegiatan yang bertujuan untuk mengetahui bahwa apa yang diamati telah sesuai dengan 
keadaan yang sebenarnya untuk mendapatkan data yang kredibilitas tinggi maka penelitian ini digunakan dalam bentuk pemeriksaan keabsahan data dengan menggunakan teknik triangulasi. Peneliti menggunakan teknik triangulasi sumber sebab teknik memeriksa keabsahan data yang memanfaatkan sesuatu yang lain diluar data sehingga data tersebut dapat dipercaya.

\section{HASIL DAN PEMBAHASAN}

Perjalanan Ombudsman sebagai lembaga negara yang mempunyai wewenang tersendiri dan dibentuk tanggal 10 Maret 2000 berusaha untuk mendampingi dalam proses pelaksanaan pengawasan pelayanan publik yang diimbangi dari peran serta masyarkat. Terdapat tiga point pemikiran dasar atas berdirinya lembaga yang mempunyai wewenang tersendiri, yaitu sebagai lembaga pemberdayaan masyarakat melalui pengawasan pelayanan publik yang jujur, bersih, transparan dan bebas KKN. Lembaga ini juga memberdayakan masyarakat terhadap kasus dari implementasi demokrasi yang perlu dikembangkan agar menghindari penyalahgunaan wewenang dan memberikan perlindungan hak-hak warga negara untuk menciptakan keadilan dan kesejahteraan.

Berdasarjan temuan penelitian, Ombudsman RI Perwakilan Sumatera Barat, menjelaskan dalam rangka pelaksanaan fungsi pengawasan terhadap pelayanan publik di Provinsi Sumatera Barat, ada beberapa bentuk pelaksananaan pengawasan yang dilakukan oleh Ombudsman RI Perwakilan Sumatera Barat. Adapun bentuk pelaksanaan pengawasan yang dilakukan Ombudsman RI Perwakilan Sumatera Barat terbagi menjadi 2 bidang, yaitu :

\section{Bidang Pemeriksaan Laporan}

a) Menerima laporan

Menerima Laporan atas dugaan maladministrasi, dalam penyelnggaran pelayanan publik laporan yang masuk ke Ombudsman RI Perwakilan Sumatera Barat adalah mengenai informasi dari masyarakat bahwa adanya dugaan penyimpangan terhadap pelaksanaan pelayanan publik di sektor tertentu dalam pemerintahan. Dugaan tersebut dapat diproses apabila sudah ada laporan yang masuk sebagai dasar Ombudsman bertindak. Dalam hal ini pengawasan dilakukan Ombudsman RI Perwakilan Sumatera Barat, yaitu menunggu adanya laporan pengaduan yang masuk, baik secara langsung, e-mail, investigasi inisiatif, media, surat, telephon, dan lain sebagainya.

b) Melakukan Pemeriksaan

Melakukan pemeriksaan substansi atas laporan, pemeriksaan dilakukan guna meminta penjelasan, mengkonfirmasi tanggapan, meminta dokumen dan lainnya dari terlapor atau pihak terkait agar bersesuaian antara laporan yang masuk dengan kenyataan yang terjadi di lapangan. Selain hal tersebut, investigasi juga dilakukan agar Ombudsman tidak salah melakukan penindakan karena penindakan dilakukan untuk perbaikan setiap lini pelayanan publik.

“...Setelah laporan masuk, maka Ombudsman langsung melakukan pemeriksaan untuk mendapatkan kesimpulan apakah laporan yang masuk layak untuk dilanjutkan tidak. Mengenai berat tidaknya laporan maladministrasi yang masuk akan ditentukan setelah selesai pemeriksaan".

Fakta tersebut memberikan gambaran bahwa tidak semua laporan yang masuk akan ditindaklanjuti langsung oleh Ombudsman melainkan ada mekanisme tertentu sebelum mengambil tindakan 
pencegahan dalam setiap maladministrasi dalam sektor pelayanan yang dilaporankan masyarakat.

\section{c) Menindaklanjuti Laporan}

Ombudsman menerima laporan-laporan dari masyarakat tentang adanya dugaan praktik maladministrasi yang di lakukan oleh oknum-oknum pemberi pelayanan publik. Dan setiap warga berhak untuk menyampaikan laporannya kepada Ombudsman RI Perwakilan Sumatera Barat, hal itu untuk menjamin terwujudnya kualitas pelayan publik yang berkualitas agar dapat menyejahterakan masyarakat.

"...Laporan yang masuk ke Ombudsman akan di registrasi dan akan diverifikasi terlebih dahulu untuk melihat apakah Ombudsman berwenangatau tidak untuk menindaklanjuti laporan tersbut. Apabila Ombudsman berwenang menindaklanjuti laporan tersebut maka Ombudsman akanmeminta klarifikasi dari pelaporan, kemudian melakukan investigasi, dan solusinya adalah melakukan mediasi antara kedua belah pihak"

\section{d) Investigasi}

Investigasi atas prakarsa sendiri terhadap dugaan maladministrasi dalam penyelnggaraan pelayanan publik Bentuk pengawasan aktif yang dilakukan Ombudsman RI Perwakilan Sumatera Barat sebagaimana yang telah diamanatkan dalam Undang-Undang Nomor 37 Tahun 2008 ialah melakukan investigasi atas prakarsa sendiri. Ombudsman RI Perwakilan Sumatera Barat dapat melakukan Investigasi melalui proses pemantauan, dan penelitian baik dibelakang meja maupun turun langsung ke lapangan. Ombudsman merupakan lembaga pengawas pelayanan publik yang independent dan mempunyai hak imunitas dimana hal tersebut mendukung Ombudsman RI Perwakilan
Sumatera Barat untuk melakukan investigasi atas prakarsa Ombudsman itu sendiri pada pelayanan publik.

\section{e) Rekomendasi}

Rekomendasi Ombudsman dapat diartikan sebagai saran atau nasihat kepada pejabat publik dalam hal ini sebagai terlapor agar mematuhi hal-hal disimpulkan dalam rekomendasi tersebut. Apabila pihak pelapor dan terlapor tidak bersepakat untuk menyelesaikan kasus dengan cara mediasi, maka akan dilanjutkan pada tahap selanjutnya yaitu Ombudsman menerbitkan surat rekomendasi kepada instansi terkait ataupun atasan terlapor berdasarkan hasil investigasi dan temuan data-data ataupun informasi yang diperoleh.

f) Monitoring

Monitoring ini dilakukan Ombudsman RI Perwakilan Sumatera Barat dalam rangka meningkatkan kualitas pelayanan publik di Sumatera Barat. Bentuk pelayanan publik sangat banyak, sehingga perlu diperhatikan oleh lembaga pengawas seperti Ombudsman.

\section{Bidang Pencegahan}

Dalam bidang ini Ombudsman RI Perwakilan Sumatera Barat akan melakukan pencegahan upaya maladministrasi dengan memberdayakan masyarakat yang bertujuan untuk meningkatkan kesadaran masyarakat, melakukan pencegahan terhadap maladministrasi serta meningkatkan kerjasama yang baik dengan stakeholder pelayanan publik. Peran Ombudsman dalam mengawasi dan meningkatkan kualitas pelayanan publik dilakukan melalui upaya preventif dan represif. Upaya preventif disini adalah dengan melakukan kegiatan sosialisasi dan pendidikan kepada masyarakat khususnya memberikan pemahaman dan kesadaran masyarakat atas hak pelayanan publik dan juga melakukan kegiatan diskusi/dialog interaktif sebagai

6 | Jurnal Mahasiwa Ilmu Administrasi Publik | Volume 2 | Nomor 4 | Tahun 2020 | (Hal. 1-9) 
bentuk koordinasi dan kerjasama dengan lembaga lain, misalnya bekerjasama dan melakukan koordinasi dengan lembaga negara atau lembaga pemerintahan lainnya serta lembaga permasyarakatan atau perseorangan, dan sebagainya untuk meningkatkan kualitas pelayanan publik yang lebih baik. Sedangkan dalam upaya represif, upaya Ombudsman ri Perwakilan Sumatera Barat adalah melakukan pencegahan dengan menerima laporan atau pengaduan masyarakat terkait keluhan yang diduga terdapat maladministrasi. Dengan demikian, kerjasama yang dibangun dengan stakeholders akan memudahkan koordinasi terkait penyelesaian / penanganan pengaduan masyarakat.

Faktor Penghambat Pelaksanaan Pengawasan Ombudsman RI Perwakilan Sumatera Barat terhadap Pelayanan Publik di Provinsi Sumatera Barat

Adel Wahidi selaku Kepala Keasistenan Bidang Pencegahan Ombudsman RI Perwakilan Sumatera Barat mengatakan bahwasanya adapun faktor yang menghambat proses pelaksanaan Pengawasan Ombudsman RI Perwakilan Sumatera Barat terhadap Pelayanan Publik di Kota Padang adalah :

a) Kurangnya Sumber Daya Manusia (SDM)

Hal besar yang menjadi penghambat dalam pelayanan publik untuk Ombudsman RI Perwakilan Sumatera Barat adalah masalah SDM karena jumlah SDM yang ada di Ombudsman Republik Indonesia Perwakilan Nusa Tenggara Barat cuma 12 orang padahal telah diketahui bersama bahwa SDM sangat penting sebagai penyedia layanan.

“...Jika dilihat dari luas wilayah, tentu jumlah kami yang hanya beberapa orang tidak mampu mengatasi seluruh wilayah Sumatera Barat namun untuk menanggulangi kekurangan tersebut, kami melakukan kerjasama dengan berbagai macam instansi di seluruh kabupaten/kota di seluruh Sumatera Barat agar permasalahan yang ada dapat di tindaklanjuti dengan cepat”.

Karena merasa kekurangan SDM, Ombudsman RI Perwakilan Sumatera Barat tidak merasa kurang dalam melayani masyarakat yang datang melapor atau melalui media yang lain.

b) Tidak Adanya Perwakilan Ombudsman di Kabupaten/Kota

Selain masalah SDM, ternyata hal besar yang menjadi kendala dalam proses pelayanan yang diberikan oleh Ombudsman RI Perwakilan Sumatera Barat adalah tidak adanya perwakilan di setiap kabupaten dan kota sehingga setiap ada laporan yang masuk, khususnya dari daerah 3T akan ditunggu dulu sampai banyak laporan, baru akan diproses oleh Ombudsman. Hal tersebut tentu akan memperlambat proses pelaksanaan laporan.

“...Dengan tidak adanya perwakilan di setiap kabupaten/kota akan cendrung membuat Ombudsman kualahan karena jika hanya berpatokan dengan perwakilan di provinsi, tentu akan membuat permasalahan yang dilaporkan oleh masyarakat tidak cepat selesai karena permasalahan masyarakat yang berhubungan dengan pelayanan publik di kabupaten/kota sangat beragam, baik dari aspek pendidikan, kesehatan, dan lain sebagainya".

c) Minimnya Anggaran

Faktor penghambat yang paling penting dalam pelaksanaan pelayanan yang dilakukan oleh Ombudsman RI Perwakilan Sumatera Barat adalah faktor anggaran. Berdasarkan hasil wawancara dengan Adel Wahidi, dia menyatakan bahwa:

"...Dana operasional yang diberikan pemerintah kepada Ombudsman RI Perwakilan Sumatera Barat adalah 
sebesar Rp. 750.000.000 per tahun tetapi dana tersebut belum bisa memenuhi operasional yang dilakukan, dana operasional yang dimaksud adalah dana untuk sosialisasi dan dana investigasi lapangan. Dana untuk sosialisasi dan investiasi sangat banyak karena mencakup semua wilayah yang ada di Provinsi Sumatera Barat".

Lebih lanjut, Adel Wahidi menyatakan :

“...Ombudsman Republik Indonesia mengajukan dana ke DPR sebesar Rp. 250.000.000.000 sampai Rp. 300.000.000.000 per tahun namun yang di setujui oleh DPR adalah 140.000.000.000 sampai Rp. 150.000.000.000 sehingga dana inilah yang di bagi ke setiap perwakilan Ombudsman di provinsi seluruh Indonesia minim, termasuk di Provinsi Sumatera Barat yang jumlahnya Rp. 750.000 .000 (tujuh ratus lima puluh juta rupiah) per tahun padahal dana yang di butuhkan oleh Ombudsman Perwakilan RI Perwakilan Sumatera Barat adalah Rp. 1.000.000.000 (satu milyar rupiah) per tahun untuk kebutuhan sosialisasi dan investigasi yang sangat besar di seluruh kabupaten/kota yang ada di Provinsi Sumatera Barat".

\section{PENUTUP}

Berdasarkan uraian diatas, maka kesimpulan yang dapat diambil adalah :

1. Pelaksanaan fungsi pengawasan Ombudsman RI Perwakilan Sumatera Barat terhadap pelayanan publik di Provinsi Sumatera Barat Barat dilakukan dalam 2 (dua) bidang, yaitu bidang pemeriksaan laporan dan bidang pencegahan. Bidang pemeriksaan laporan terdiri dari menerima laporan atas dugaan maladministrasi dalam penyelnggaran pelayanan publik, melakukan pemeriksaan substansi atas laporan, menindaklanjuti laporan yang tercakup dalam ruang lingkup kewenangan Ombudsman, melakukan investigasi atas prakarsa sendiri terhadap dugaan maladministrasi dalam penyelnggaraan pelayanan publik, rekomendasi, dan monitoring. Sementara bidang pencegahan terdiri dari melakukan koordinasi dan kerjasama dengan lembaga negara atau lembaga pemerintahan lainnya serta lembaga permasyarakatan dan perseorangan, membangun jaringan kerjasama, melakukan upaya pencegahan maladministrasi, serta melakukan tugas lain yang diberikan undang-undang. Kedua bidang tersebut berdasarkan hasil penelitian yang dilakukan sudah dijalankan dengan baik meskipun ada kendala-kendala teknis yang dihadapi.

2. Faktor penghambat pelaksanaan pengawasan Ombudsman RI Perwakilan Sumatera Barat terhadap pelayanan publik di Provinsi Sumatera Barat adalah kurangnya Sumber Daya Manusia (SDM), tidak adanya perwakilan Ombudsman di kabupaten/kota, dan kurangnya anggaran.

Saran penyusun dalam penelitian ini adalah : 1) Ombudsman RI Perwakilan Sumatera Barat agar lebih rutin melakukan koordinasi dan kerjasama dengan lembagalembaga terkait dan membangun jaringan agar lebih mudah mensosialisasikan fungsi Ombudsman terhadap pelayanan publik, khususnya di Provinsi Sumatera Barat dan 2) Hendaknya Ombudsman RI Perwakilan Sumatera Barat mengoktimalkan jumlah SDM, membentuk jaringan di tingkat kabupaten/kota di Provinsi Sumatera Barat, agar laporan yang masuk dari masyarakat tidak bertele-tele dan cepat dalam proses penyelesainnya. Kemudian pemerintah hendaknya menambah dana operasional Ombudsman RI Perwakilan Sumatera Barat sesuai dengan kebutuhan sehingga 
pelaksanaan fungsi pengawasan dapat terlaksana dengan lancer.

\section{DAFTAR KEPUSTAKAAN}

Aldri Frinaldi. 2014. Pengaruh Budaya Kerja PNS Terhadap Pelayanan Publik Di Dinas Catatan Sipil

Asmara, Galang, Ombudsman Republik Indonesia dalam Sistem Ketatanegaraan Republik Indonesia, (Surabaya: Laksbang Yustisia, 2012).

Budiarti, Lilin 2012 Good Governance Dalam Pengelolaan Lingkungan Hidup. Bogor: Ghalia Indonesia.

Denim, Sudarwan, Menjadi Peneliti Kualitatif, (Bandung: Pustaka Setia, 2002).

Dwiyanto, Agus 2006.Mewujudkan Good Governance Melayani Publik. Yogyakarta: UGM Press.

Erma Safitri, "Pengaruh Pelatihan Dan Disiplin Kerja Terhadap Kinerja Karyawan" (Jurnal Ilmiah Manajemen, Vol No 4, 2013).

Faustino Cardoso Gomes. 1999 Manajemen Sumber Daya Manusia, Yogyakarta: Andi.

Fahmal, H.A. Muin, Peran Asas-asas Umum Pemerintahan yang Layak dalam Mewujudkan Pemerintahan yang Bersih, (Yogyakarta: UII Press, 2006).

Galang Asmara, Ombudsman Nasional dalam Sistem Pemerintahan Negara Republik Indonesia, Laksbang Pressindo, Yogyakarta, 2005.

Mukti Fajar dan Yulianto, Dualisme Penelitian Hukum Normatif dan
Empiris, Yogyakarta: Pustaka Pelajar, 2010.

Puspitosari, Hesti; et. al., 2012,Filosofi Pelayanan Publik, Setara Press (Kelompok Intrans Publishing) dan JaringanNasional Masyarakat Peduli Pelayanan Publik (MP3), Malang Surtan Siahaan, Peran Strategis Ombudsman RI Dalam Pengawasan Pelayanan Publik.

https://www.kompasiana.com/_fr3dy_pera n-stratregis-ombudsman-ridalampengawasan-pelayananpublik_54f3fd45745513a02b6c839c.

Thamrin Husni,2013,Hukum Pelayanan Publik di Indonesia, Yogyakarta:Aswaja Pressind.

UU Nomor 37 Tahun 2008 Tentang Ombudsman Republik Indonesia.

UU Ombudsman Nomor 14 Tahun 2008 Tentang Keterbukaan Informasi Publik.

UU Ombudsman Nomor 25 Tahun 2009 Tentang Pelayanan Publik.

UU Ombudsman Nomor 32 Tahun 2004 Tentang Pemerintahan Daerah. 